УДК 621.311.25:628.33.35

Doi: https://doi.org/10.32918/nrs.2019.1(81).11

\section{Очищення рідких} радіоактивних відходів від поверхнево-активних речовин і органічних сполук

Ганем Хуссам

Одеський національний політехнічний університет, м. Одеса, Україна

ORCID: https://orcid.org/0000-0002-2416-198X

Герлига В. А.

Відокремлений підрозділ «Науково-технічний центр»

ДП НАЕК «Енергоатом», м. Одеса, Україна

ORCID: https://orcid.org/0000-0002-3627-9475

Кравченко В.П.

Одеський національний політехнічний університет, м. Одеса, Україна

ORCID: https://orcid.org/0000-0002-7557-3327

Македон В. В.

Відокремлений підрозділ «Науково-технічний центр»

ДП НАЕК «Енергоатом», м. Одеса, Україна

ORCID: https://orcid.org/0000-0002-6727-7755

Шульга О.В.

Відокремлений підрозділ «Науково-технічний центр»

ДП НАЕК «Енергоатом», м. Одеса, Україна

ORCID: https://orcid.org/0000-0002-6022-6269

В процесі експлуатації АЕС утворюється та накопичується значна кількість рідких радіоактивних відходів (РРАВ), переробка яких є одним з першочергових завдань. Одним з джерел рідких радіоактивних відходів $\epsilon$ трапні води до складу яких входять поверхнево-активні речовини (ПАР) та органічні сполуки (ОС) різної природи. При даному складі відходів значно ускладняється робота випарних апаратів. Тому, переробка вод суттєво спрощується після їх очищення від ПАР та ОС. У роботі розглянуті теоретичні аспекти окислювально-кавітаційного та електро-гідророзрядного очищення вод від органічних речовин. Розроблені та приведені принципові схеми експериментальних стендів комбінованих методів очищення. Дослідження проводили на модельних розчинах лаурилсульфату натрію (ЛС) $\left(\mathrm{NaC}_{12} \mathrm{H}_{25} \mathrm{SO}_{4}\right)$ та етилендиамінтетраоцтової кислоти (ЕДТА) $\left(\mathrm{C}_{10} \mathrm{H}_{16} \mathrm{~N}_{2} \mathrm{O}_{8}\right)$. ЛС вибраний з огляду на те, що це найбільш поширена поверхнево-активна речовина, яка присутня в складірізних миючих та дезактивуючих сумішей. Використання ЕДТА зумовлено його застосуванням в технологічних процесах на AEC та наявністю у складі рідких радіоактивних відходів. Руйнування органічних з'єднань відбувається в результаті окислення озоном, що постійно барботується через розчин, та посилюється дією електричних імпульсів або ультразвуковою (УЗ) кавітацією. В роботі визначені закономірності зниження концентрацій модельних розчинів у залежності від способу обробки, $\mathrm{pH}$ середовища та тривалості процесу. Встановлено, що деструкція ПАР та ОС найкраще протікає при спільному використанні озону і УЗ кавітації або електричного розряду, при високих значеннях рН. Найвищі показники ефективності очищення розчинів наступні: при використанні розрядів і озону $(p H=6,2)$ руйнується 71 \% ПАР, при $\mathrm{pH}=10$ руйнується $61 \%$ ОС; при використання УЗ кавітації та озону $(p H=10)$ руйнується 83,3 \% ПАР.

К лючо в і сл о в а: очищення води від поверхнево-активних речовин іорганічних сполук, електро-гідророзрядний метод, окислювання озоном

() Ганем Хуссам, Герлига В. А., Кравченко В.П., Македон В. В., Шульга О.В., 2019
B ажливим відкритим питанням при очищенні побутових вод і промислових стоків є усунення поверхнево-активних речовин і органічних забруднень [1,2]. Крім того традиційні методи очищення стічної води значно спрощуються при попередньому видаленні з вихідної води ПАР та органічних сполук [3].

При експлуатації АЕС переробка рідких радіоактивних відходів є одним із першочергових завдань [4]. При дезактивації обладнання, а також при роботі спецпралень утворюється значна кількість забруднених радіоактивними елементами розчинів. Ці розчини містять комплекси органічних сполук та ПАР, які ускладнюють виділення радіонуклідів традиційними фізико-хімічними методами. Очевидно, що локалізація, концентрування і переробка рідких радіоактивних відходів значно спрощується після видалення або руйнування вищенаведених сполук.

3 аналізу існуючих методів знезараження промислових та побутових стічних вод, випливає, що одним 3 найбільш ефективних способів очищення, $є$ окиснення домішок за допомогою озону. Також перспективними, але в повній мірі не реалізованими способами очистки водних розчинів від органічних та біологічних забруднень $є$ такі, що використовують кавітацію, джерелом якої служать ультразвукові коливання.

Одним з нетрадиційних, але перспективних способів знезараження і очищення водних розчинів $\epsilon$ електроімпульсний метод [5]. Де основним принципом роботи $€$ здійснення високовольтних розрядів в рідині, що перспективно з точки зору безпосереднього введення в оброблювану воду окислювачів.

В даній роботі наведено результати досліджень електро-гідророзрядного та окислювально-кавітаційного очищення водних розчинів від органічних речовин і ПАР, які можуть бути застосовані при розробці відповідної комбінованої технології, що дозволяє спростити переробку рідких радіоактивних відходів.

\section{Теоретичні основи окислювально-кавітаційного та електро-гідророзрядного очищення води від органічних речовин і пар}

Основними радіонуклідами в трапних водах AEC $є$ Cs134, Cs-137, Со-60, Мn-54. Радіоактивні речовини в розчинах знаходяться у вигляді простих і комплексних (органічні і неорганічні сполуки з великою молекулярною масою) іонів, нейтральних молекул і колоїдних частинок. Аналіз літературних даних і наявний практичний досвід свідчить про те, що найбільш ефективним способом для видалення комплексів є їх окиснення до простіших складових [6-9]. Але, незважаючи на велику кількість публікацій, слід визнати очевидним і той факт, що недостатньо повно вивчені способи усунення негативного впливу комплексних сполук на процес сорбції.

Відомо, що в даний час найбільш перспективним способом знешкодження рідких радіоактивних відходів є сорбційне вилучення радіонуклідів 3 розчинів [10]. Однак, на даний процес істотно впливають комплекси, які наявні в рідких радіоактивних відходах.

Використання ультразвукової обробки дозволяє зменшити кількість цих комплексів шляхом кавітаційного руйнування органічних сполук радикалами, в тому числі і $O H$, що утворюються в процесі кавітації та за рахунок збільшення кількості розчиненого озону в розчині шляхом руйнування бульбашок киснево-озонної суміші. 
Руйнування комплексів з використанням електро-гідророзрядної технології є технічно легко втілюваним і екологічно чистим методом. Електричні розряди формують ударні хвилі, в результаті чого може утворюватись гідроксильний активний радикал, а також атомарний кисень, пероксид водню та інші, кожен з яких є ефективним засобом проти біологічних і хімічних забруднень в різних розчинах.

\section{Відомості про електрогідравлічний ефект}

Електрогідравлічний ефект - спосіб перетворення електричної енергії в механічну, що відбувається без посередництва проміжних механічних ланок, 3 високим коефіцієнтом корисної дії. Сутність цього способу полягає в тому, що при здійсненні всередині об’єму рідини, що знаходиться у відкритому чи закритому посуді, спеціально сформованого імпульсного електричного (іскрового, та інших форм) розряду, навколо зони його утворення виникають надвисокі гідравлічні тиски, здатні здійснювати корисну механічну роботу та які супроводжуються комплексом фізичних і хімічних явищ.

Основними діючими факторами електрогідравлічного ефекту є значні імпульсні переміщення об’ємів рідини, що відбуваються зі швидкостями, що досягають сотень метрів в секунду; виникають потужні кавітаційні процеси, здатні охопити відносно великі об'єми рідини [11]; інфра- та ультразвукові випромінювання; механічні резонансні явища. Всі ці фактори дозволяють надавати рідині і об'єктам, які розміщені в ній, дуже різноманітні фізичні і хімічні впливи.

\section{Кавітація та її фізико-хімічні властивості}

Кавітація - це явище, яке включає утворення, зростання і руйнування каверн або пустот в рідині під дією флуктуацій тиску. Кавітація може викликати дегазацію рідини, ініціювати вільно-радикальні реакції, прискорювати хімічні реакції завдяки полегшенню змішування реагентів, підвищувати швидкість емульгування, покращувати дифузійні процеси, утворювати висококонцентровані емульciї або гомогенні дисперсії, сприяти екстракції речовин, видаляти і руйнувати певні частинки і мікроорганізми.

В процесі кавітації виникають високі місцеві температура і тиск, в поєднанні з надзвичайно швидким охолодженням, що забезпечує здійснення хімічних реакцій в екстремальних умовах. Ці реакції, як правило, характеризуються одночасною появою піролізу і радикальних реакцій. Найбільш важливим результатом кавітації $\epsilon$ ініціалізація вільнорадикальних реакцій, в першу чергу завдяки утворенню гідроксильного радикала - $\mathrm{OH}$, який володіє високою реакційною здатністю і може окислювати велику кількість органічних речовин в розчині. Органічні сполуки розщеплюються при кавітації до простих органічних кислот, неорганічних іонів, $\mathrm{CO}, \mathrm{CO}_{2}$ i $\mathrm{H}_{2} \mathrm{O}$. Відбувається руйнування багатьох хлорорганічних сполук [12,13].

Під дією кавітації прискорюються реакції механо-хімічного походження, в тому числі вони дозволяють змінити просторову орієнтацію і властивості молекул, деформувати, розривати молекулярні ланцюжки на окремі фрагменти.

\section{Озон та його фізико-хімічні властивості}

Озонування - технологія очищення, основана на використанні газу озону - сильного окисника. Озонатор виробляє озон з кисню, що міститься в атмосферному повітрі або кисневому балоні. При виробництві озону необхідно видаляти вологу з повітря, інакше в озонаторі буде утворюватися азотна кислота. При взаємодії з хімічними речовинами та мікроорганізмами (всі вони з хімічної точки зору добре окислюються) озон перетворюється в атомарний та звичайний кисень. Після окиснення, продукти реакції частково залишаються розчиненими в рідкій фазі, частково випадають в осад або утворюються газоподібні речовини [14].

Озон є одним з найбільш зручних окислювальних реагентів і має високий окиснювальний потенціал. Озон розкладається з утворенням кисню і при цьому, його застосування не призводить до утворення вторинних відходів. Однак, озонуванню притаманний і ряд недоліків, основними з яких є відносно низька продуктивність озонаторів і відносно низька розчинність озону в воді. Ефективність окиснення озоном органічних речовин можна підвищити, збільшивши концентрацію і розчинність озону в окислювальному середовищі за допомогою кавітаційного руйнування бульбашок, які містять озон.

Озон в розчинах має наступні фізико-хімічні властивості [14]:

- осаджує іони заліза, марганцю, міді - шляхом взаємодії озону і розчинених іонів металів з утворенням нерозчинних продуктів за реакціями:

$$
\begin{aligned}
& 2 \mathrm{Fe}^{2+}+\mathrm{O}_{3}+5 \mathrm{H}_{2} \mathrm{O} \rightarrow 2 \mathrm{Fe}(\mathrm{OH})_{3} \downarrow+\mathrm{O}_{2}+4 \mathrm{H}^{+} \\
& 2 \mathrm{Cu}^{2+}+2 \mathrm{O}_{3}+4 \mathrm{H}_{2} \mathrm{O} \rightarrow 2 \mathrm{Cu}(\mathrm{OH})_{2} \downarrow+3 \mathrm{O}_{2}+4 \mathrm{H}^{+} \\
& 2 \mathrm{Mn}^{2+}+2 \mathrm{O}_{3}+4 \mathrm{H}_{2} \mathrm{O} \rightarrow 2 \mathrm{Mn}(\mathrm{OH})_{2} \downarrow+3 \mathrm{O}_{2}+4 \mathrm{H}^{+}
\end{aligned}
$$

- розщеплює ненасичені вуглеводні, шляхом розриву молекул по $\mathrm{C}=\mathrm{C}$ зв'язку;

- окислює ароматичні вуглеводні з утворенням менших органічних складових;

- підвищує ефект коагуляції (збільшує розмір пластівців, підвищує швидкість осадження) за рахунок утворених в процесі окиснення органічних речовин, полярних молекул і іонів, які сприяють коагуляції;

- покращує флокуляцію. Це обгрунтовується тим, що озон дестабілізує колоїдні частинки (такі, що знаходяться в підвішеному стані), через що вони краще осаджуються.

\section{Склад експериментальних стендів та їх оснащення. \\ Електро-гідророзрядне очищення води від органічних сполук і ПАР}

Лабораторний стенд електро-гідророзрядного очищення від органічних сполук та ПАР (Рис. 1) складається 3 двох основних секцій - генератора імпульсних струмів (ГїС) та безпосередньої обробки.

ГїС призначений для створення імпульсних струмів, регулювання їх потужності та частоти. Потужність імпульсів регулюється за допомогою автотрансформатора, який включений в первинну обмотку високовольтного трансформатора (15), а частота - зміною відстані між мідними півсферами в розряднику (2): 


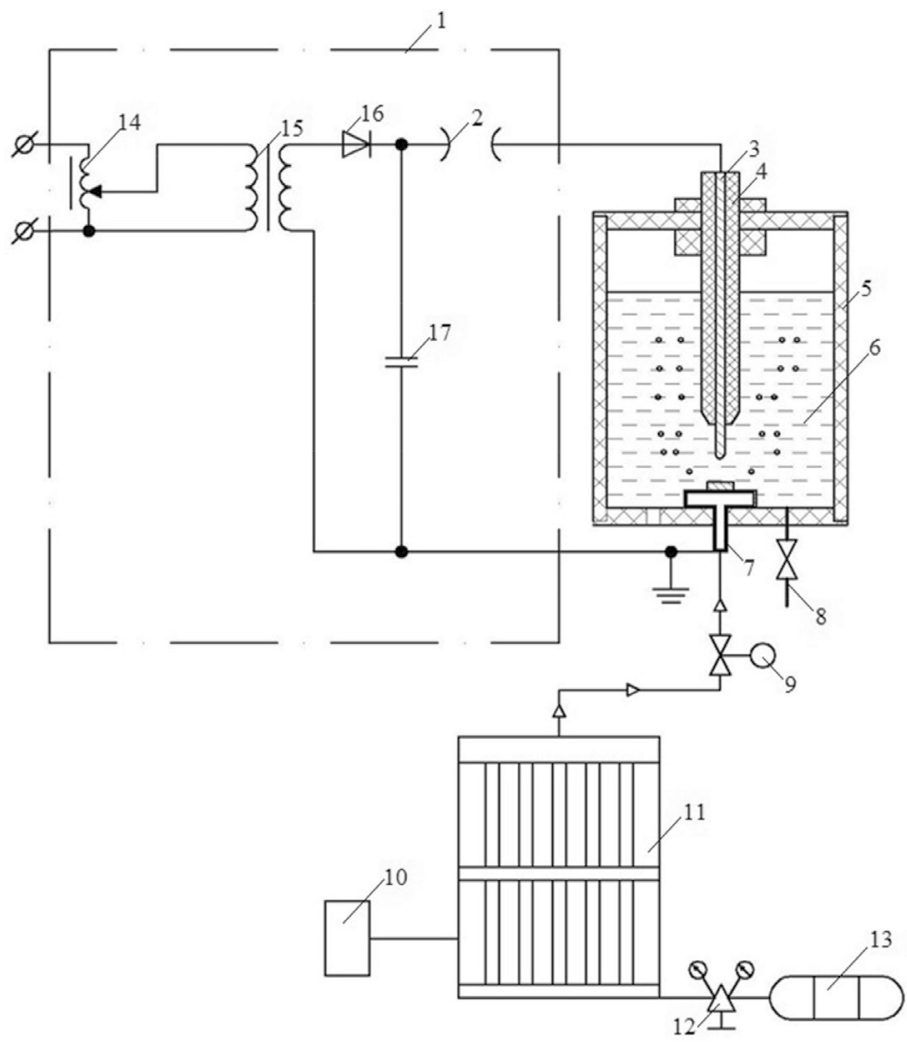

Рис. 1 - Принципова схема стенду електро-гідророзрядного очищення води від органічних сполук та ПАР:

1 - генератор імпульсних струмів; 2 - розрядник;

3 - сталевий електрод; 4 - ізоляція; 5 - реактор;

6 - робочий розчин; 7 - сталевий електрод з барботажем;

8 - пробовідбірник; 9 - ротаметер; $10-$ пульт управління озонатору; 11 - озонатор; 12 - редуктор;

13 - кисневий балон; $14-$ узгоджувальний трансформатор, 15 - високовольтний трансформатор, 16 - високовольтний діод,

17 - накопичувальний конденсатор.

$$
W=\frac{C U^{2}}{2},
$$

де: W - енергія електричного імпульсу;

C - ємність розрядного конденсатору;

$\mathrm{U}$ - напруга на розрядному конденсаторі.

Високовольтні імпульси з ГїС надходять до електроду (3) з ізоляцію (4). Контур електричного струму замикається на електроді з перфорацією (7) до якого підведене заземлення.

Озон утворюється в озонаторі (11) - «Бозон-КСВ» 3 кисню, що міститься в балоні (13). Контроль тиску в кисневому балоні та витрати киснево-озонної суміші в реакторі відбуваються за допомогою редуктора (12) та ротаметра (9) - РМ-02-0,63 ГУЗ. Керування озонатором проводиться 3 пульта управління (10). Відбір проб та злив води для промивки реактора здійснюється через пробовідбірник (8).

Деструкція ПАР та органічних сполук відбувається в реакторі за рахунок окиснення озоном, що підсилюється електричним розрядом, який виникає між електродами (3) та (7).

\section{Окислювально-кавітаційне очищення води від органічних сполук і ПАР}

Дослідницька установка окислювально-кавітаційного очищення складається $з$ двох основних вузлів (Рис. 2).

Тиск в контурі першого вузла становить $\mathrm{P}=0,1-$ 0,15 МПа та контролюється за допомогою редуктора. Концентрація озону в киснево-озоновій суміші $\mathrm{C}_{\mathrm{o}}=60 \mathrm{мг} /$ дм ${ }^{3}$ фіксується на пульті керування генератора озону (8). Витрата киснево-озонової суміші $\mathrm{G}=15$ дм $^{3} /$ год. регулюється за допомогою ротаметру (7) - РМ-02-0,63 ГУЗ.

Реактор представляє собою циліндр з нержавіючої сталі, до торців якого прикріплені п'єзокерамічні випромінювачі, які перетворюють високочастотні (f $=22$ кГц) електричні коливання в механічні пульсації, які в свою чергу генерують кавітаційні каверни.

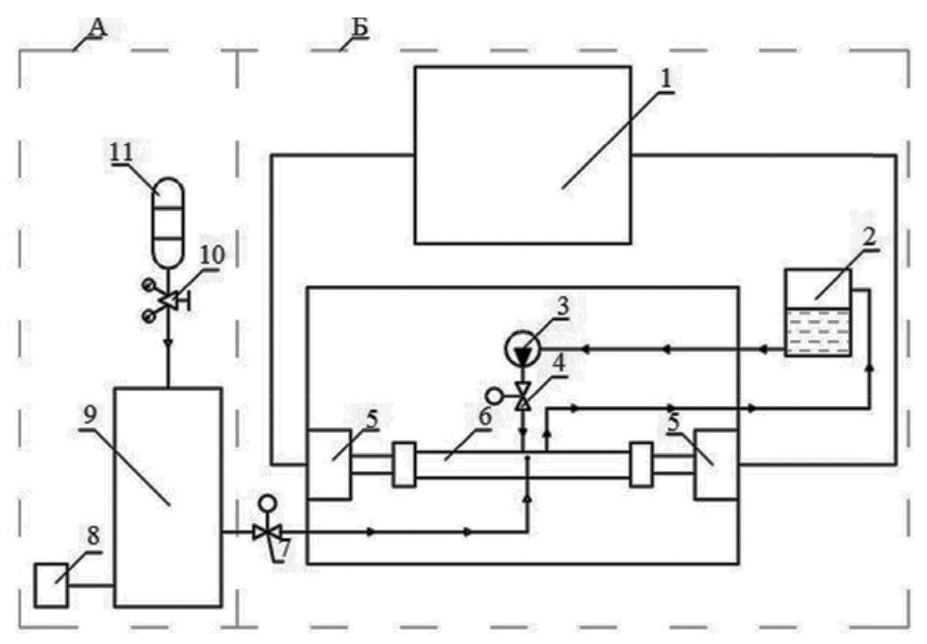

Рис. 2 - Принципова схема стенду окислювальнокавітаційного очищення води від органічних сполук та ПАР: $A-$ вузол генерації та подачі озону, $D$ - вузол комплексної обробки розчинів, 1 - генератор електричних коливань; 2 - ємність 3 робочим розчином; 3 - перистальтичний насос; 4 - манометр;

5 - п'єзокерамічні випромінювачі; 6 - сталевий реактор; 7 ротаметр; 8 - пульт керування генератором озону; 9 - генератор озону «Бозон-КСВ»; 10 - редуктор; 11 - балон з киснем

Руйнування органічних домішок відбувається завдяки їх окисненню озоном, який барботується у вигляді кисневоозонової суміші, в середовище ультразвукової кавітації.

\section{Експериментальне дослідження очищення води від ПАР і органічних сполук}

Підбір досліджуваних розчинів та аналізованих показників лімітувався можливістю проведення їх аналізу в умовах лабораторій та обмеженим апаратурним забезпеченням.

\section{Випробування стенду електро-гідророзрядного очищення води від органічних сполук і ПАР}

Проведення пробних випробувань установки проводилось намодельних розчинахлаурилсульфатунатрію $\left(\mathrm{NaC}_{12} \mathrm{H}_{25} \mathrm{SO}_{4}\right)$ 3 концентрацією $\mathrm{C}_{\text {лс }} \approx 0,35$ ммоль/дм ${ }^{3}$, який використовувався у якості ПАР та на модельному розчині етилендиамінтетраоцтової кислоти $\left(\mathrm{C}_{10} \mathrm{H}_{16} \mathrm{~N}_{2} \mathrm{O}_{8}\right)$ концентрацією 
$\mathrm{C}_{\text {ЕдтА }} \approx 3,7$ ммоль/дм ${ }^{3}$, яка використовувалась у якості органічних домішок. ЛС вибраний з огляду на те, що це найбільш поширена поверхнево-активна речовина (аніоноактивна), часто використовується в складі різних миючих сумішей. Вибір низької концентрації ЛС, близькій 0,35 ммоль/дм ${ }^{3}$ $\left(0,1\right.$ г/дм $\left.{ }^{3}\right)$, зумовлений пї фізичними властивостями. Розчини 3 концентрацією ЛС $>1,5$ ммоль/дм ${ }^{3}\left(0,5\right.$ г/дм $\left.{ }^{3}\right)$ характеризуються сильним піноутворенням в умовах проведення дослідів, що призводить до зменшення концентрації ЛС у рідкій фазі. Використання для досліджень ЕДТА зумовлено його використанням в технологічних процесах на АЕС та наявністю у складі рідких радіоактивних відходів.

\section{Результати випробувань стенду електро-гідророзрядного очищення води від органічних сполук і ПАР}

Руйнування органічних домішок проводили в електрогідророзрядній установці з барботажем киснево-озонової суміші через рідину. Досліджувались розчини ЛС та ЕДТА, тривалість обробки становила 60 хвилин при різних показниках $\mathrm{pH}$ середовища.

Параметри роботи електро-гідророзрядної установки:

номінальна потужність установки: $\mathrm{N}=1$ кВт;

частота імпульсів, f 2 Гц;

відстань між електродами, $\mathrm{h}=3$ мм;

робочий об'єм реактора, $\mathrm{V}=5$ дм $^{3}$;

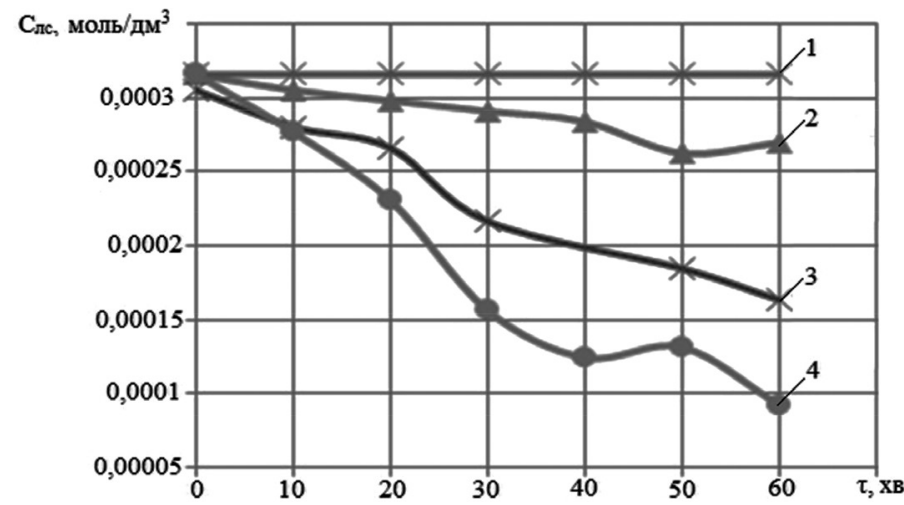

Рис. 3 - Графік зміни концентрації ЛС з часом обробки: $1-$ Гї ; $2-$ озон; $3-$ Гї + озон, $\mathrm{pH}=3,7 ; 4-\Gamma \dot{\mathrm{I}} \mathrm{C}+$ озон $\mathrm{pH}=6,26$

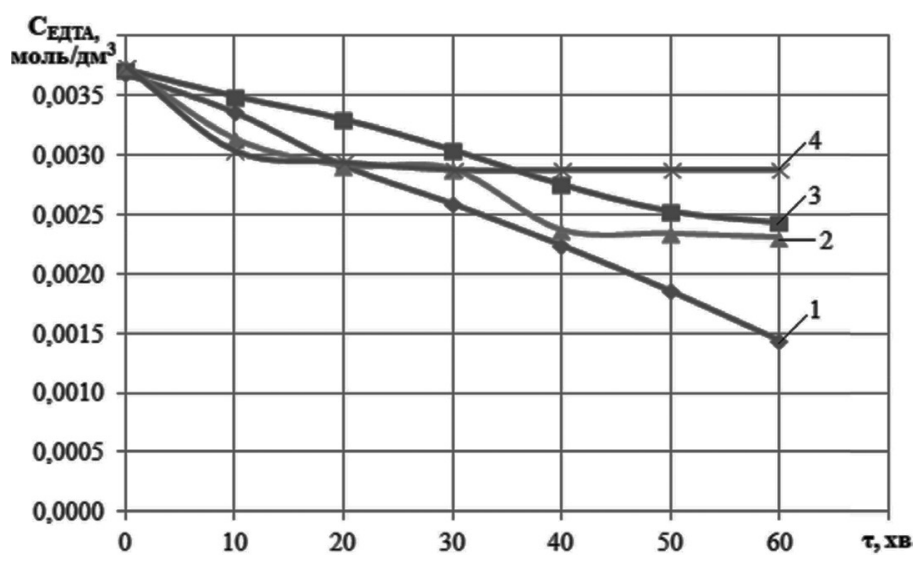

Рис. 4 - Графік зміни концентрації ЕДТА з часом обробки: $1-$ Гї + озон, $\mathrm{pH}=10,01 ; 2-$ Гї + озон, $\mathrm{pH}=6,75$ $3-$ озон, $\mathrm{pH}=11,94 ; 4-$ Гї $, \mathrm{pH}=6,98$. концентрація озону в киснево-озоновій суміші, С 60 мг/дм ${ }^{3}$;

витрата киснево-озонової суміші, $\mathrm{G} \sim 15$ дм³$^{3} /$ год.

Руйнування ЛС та ЕДТА (Рис. 4) відбувається в результаті їх окислення озоном, який барботується через робочий розчин, а також посилюється за допомогою розряду електричного струму, який виникає між електродами.

Виходячи $з$ даних експериментів видно, що обробка тільки електророзрядом на протязі 60 хв. не змінює концентрацію ЛС, проте вона має вплив на концентрацію ЕДТА, зменшуючи іï на $23 \%$. При спільному використанні розряду і озону досягалось більш глибоке руйнування зв'язків органічних домішок. Також можна сказати, що при комплексній обробці розчинів зі слабо кислим середовищем, реакція руйнування органічних сполук протікає повільніше порівняно 3 нейтральним середовищем.

В результаті проведених досліджень було встановлено, що деструкція ПАР та ЕДТА найкраще протікає при спільному використанні озону і розряду, при високих значеннях рН. Найвищі показники були отримані при обробці розчину ЛС при $\mathrm{pH}=6,26$ в процесі чого руйнується 70,8 \% ПАР. При обробці ЕДТА найглибше окиснення досягалось при рН $=10,01$ і склало 60,9 \% зменшення концентрації. Також виявлено, що розкладання ПАР електророзрядом на заданих потужностях не відбувається, а при використанні одного озону досягається зниження концентрації ПАР тільки до 14,5-16,9\%. Тобто обробка електричним розрядом і озоном окремо неефективна, і тільки їх взаємний вплив призводить до позитивного результату.

\section{Випробування стенду окислювально-кавітаційного очищення води від органічних сполук і ПАР}

Для порівняння ефективності роботи стендів випробування установки окислювально-кавітаційного очищення проводили на аналогічних робочих розчинах - лаурилсульфат натрію 3 концентрацією $\mathrm{C}_{\text {лс }} \approx 0,35$ ммоль/дм ${ }^{3}$ та ЕДТА з концентрацією $\mathrm{C}_{\text {ЕДТА }} \approx 3,7$ ммоль/дм ${ }^{3}$.

\section{Результати випробування стенду окислювально-кавітаційного очищення води від органічних сполук і ПАР}

Вивчення комплексного впливу озону та УЗ кавітації на ПАР проводилося на модельному розчині лаурилсульфату натрію. Дослідження виконували в полі ультразвукової кавітації з частотою коливань $\mathrm{f}_{\text {уз }} \approx 22$ кГц. У розчин постійно барботувалась киснево-озонова суміш з витратою

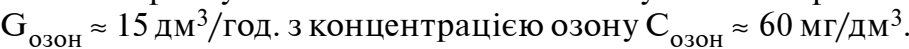
Досліди проводили при температурі робочого розчину в реакторі $30{ }^{\circ} \mathrm{C}$ і різних показниках $\mathrm{pH}$. Корегування $\mathrm{pH}$ здійснювали шляхом додавання розчинів $\mathrm{NaOH}$ або $\mathrm{H}_{2} \mathrm{SO}_{4}$.

Результати серії експериментів приведені в Таблиці 1.

У процесі обробки спостерігається зменшення концентрації ЛС у всіх досліджуваних розчинах. Застосування озону без УЗ кавітації, при наведених параметрах процесу, дозволяє зменшити кількість ЛС на 51,5 \% мас. Встановлено, що УЗ кавітація наряду з підвищенням $\mathrm{pH}$ середовища 
Ганем Хуссам, Герлига В. А., Кравченко В. П., Македон В. В., Шульга О. В.

Таблиия 1. Показники ефективності комплексної обробки

\begin{tabular}{|c|c|c|c|c|c|}
\hline \multirow[b]{2}{*}{$\begin{array}{l}\text { № } \\
\text { п/ா }\end{array}$} & \multirow[b]{2}{*}{$\begin{array}{l}\tau, \\
\mathbf{X B} .\end{array}$} & \multicolumn{4}{|c|}{ Зниження концентрації ЛС, \% } \\
\hline & & $\begin{array}{c}\text { Озон, } \\
\mathrm{pH}=5,7\end{array}$ & $\begin{array}{c}\text { Кавітація }+ \\
+ \text { озон, } \\
\text { рН = 4,9 }\end{array}$ & $\begin{array}{c}\text { Кавітація + } \\
+ \text { озон, } \\
\text { рН = 5,8 }\end{array}$ & $\begin{array}{c}\text { Кавітація }+ \\
+ \text { озон, } \\
\text { рH }=8,3\end{array}$ \\
\hline 1 & 10 & 24,24 & 27,52 & 26,12 & 26,85 \\
\hline 2 & 20 & 29,29 & 44,03 & 43,24 & 47,22 \\
\hline 3 & 30 & 38,38 & 55,04 & 47,74 & 60,18 \\
\hline 4 & 40 & 49,49 & 63,3 & 59,45 & 74,07 \\
\hline 5 & 50 & 50,50 & 72,47 & 67,56 & 80,55 \\
\hline 6 & 60 & 51,51 & 77,06 & 81,01 & 83,3 \\
\hline
\end{tabular}

позитивно впливає на динаміку окиснення ЛС. Найвищий відсоток зниження концентрації ЛС був отриманий при комплексній обробці розчину киснево-озоновою сумшшю в полі УЗ кавітації і склав 83,3 \% мас. при показнику $\mathrm{pH}$ середовища $\mathrm{pH}=8,3$.

\section{Висновки}

1. Розроблено експериментальні стенди для дослідження впливу різних способів очищення розчинів від органічних сполук та поверхнево-активних речовин. Дослідження проводилися на модельних розчинах лаурилсульфату натрію $\left(\mathrm{NaC}_{12} \mathrm{H}_{25} \mathrm{SO}_{4}\right) 3$ концентрацією $\mathrm{C}_{\text {лс }} \approx 0,35$ ммоль/дм ${ }^{3}$, який використовувався у якості ПАР та на модельному розчині етилендиамінтетраоцтової кислоти $\left(\mathrm{C}_{10} \mathrm{H}_{16} \mathrm{~N}_{2} \mathrm{O}_{8}\right)$ з концентрацією $\mathrm{C}_{\text {ЕдтА }} \approx 3,7$ ммоль/ дм $^{3}$, яка використовувалась у якості органічних сполук.

2. Експериментальна перевірка ефективності електро-гідророзрядного очищення показала, що електричні імпульси несуттєво змінюють вміст ЛС в досліджуваних розчинах, проте впливають на концентрацію ЕДТА,

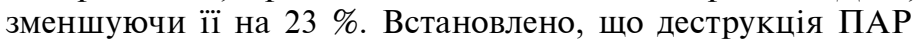
та органічних сполук найкраще протікає при спільному використанні озону і розряду, при високих значеннях $\mathrm{pH}$. Найвищі показники ефективності розкладу органічних домішок були отримані:

- при обробці розчину ЛС при $\mathrm{pH}=6,2$ в процесі чого руйнується близько $71 \%$ ПАР;

- при обробці ЕДТА при $\mathrm{pH}=10$ руйнується близько $61 \%$ органічних сполук.

3. Випробування стенду окислювально-кавітаційного очищення показало, що застосування озону без УЗ кавітації дозволяє зменшити кількість ЛС на $51 \%$ мас. Встановлено, що УЗ кавітація наряду з підвищенням рН середовища позитивно впливає на динаміку окиснення ЛС озоном. Найвищий відсоток зниження концентрації ЛС був отриманий при комплексній обробці розчину киснево-озоновою суміщу в полі УЗ кавітації і склав 83 \% мас. при показнику $\mathrm{pH}$ середовища $\mathrm{pH}=8,3$.

4. Визначено, що обробка електричним розрядом (або УЗ) і озоном окремо менш ефективна, і тільки їх взаємне застосування призводить до позитивного результату.

5. Одним із способів покращення ступеня очищення досліджуваних розчинів є підвищення продуктивності озонатору, так як сумарна маса озону, при використанні озонатору «Бозон-КСВ» за 60 хв. складала лише $~ 0,9$ г.

\section{Список використаної літератури}

1. Яковлев С. В. Очистка производственных сточных вод. М.: Стройиздат, 1986. $336 \mathrm{c.}$

2. Кучеров А. В., Шибилева О. В. Опреснение воды: современное состояние и перспективы развития. Молодой учёный. 2014. № 3 (62). С. 236-239.

3. Запольский А. К., Мішкова-Клименко Н. А., Астрелін Ї. М. та ін. Фізико-хімічні основи технології очищення стічних вод. К. : Вид-во «Лібра», 2000. 552 с.

4. МЕЖДУНАРОДНОЕ АГЕНТСТВО ПО АТОМНОЙ ЭНЕРГИИ, Обращение с радиоактивными отходами низкого и среднего уровня активности перед их захоронением, Серия норм безопасности МАГАТЭ, № WS-G-2.5, МАГАТЭ, Вена 2005.

5. Костин Н.А., Кублановский В. С., Заблудовский В. А. Импульсный электролиз. АН УССР, Ин-т общ. и неорган. химии. Киев: Наук. думка, 1989. 167 с.

6. Демидюк В. И., Ткаченко С. Н., Егорова Г. В., Попкович М.П., Лунин В.В. Разложение озона на твердых поверхностях. Третий международный конгресс “Вода: экология и технология”. Тезисы докладов. Москва, 1998. С. 649-650.

7. Кульский, Л. А., Князькова Т. В., Клименко Н. А. Перспективы мембранной очистки промышленных вод от поверхностноактивных веществ и красителей. М.: РХТУ, 1988. 46с.

8. Клименко Н. А., Когановский А. М., Панченко Н. П. Использование активных углей для очистки промышленных сточных вод от ПАВ. Химия и технология воды. 1982. Т. 4, № 1.С. 47-50.

9. Кульский Л. А., Строкач П. П., Слипченко В. А. Очистка воды электрокоагуляцией. Киев: Будівельник, 1978. 112 с.

10. Арустамов А. Э., Зинин А. В., Красников П. В. и др. Метод ионоселективной очистки жидких радиоактивных отходов атомных станций. Безопасность жизнедеятельности. - № 11. 2005. ULR: http://www.proatom.ru/modules.php? name=News\&file=article\&sid=296

11. Пивоваров А. А., Николенко Н. В., Захаров Р. И. и др. Термодинамический анализ химических превращений в «активированных» плазмой водных растворах хлорида натрия. Вопр. химии и хим. технологии. 2012. № 3. С.127-133.

12. Предзимірська Л. М. Кавітаційне очищення природних і стічних вод від органічних та біологічних забруднень : дис. канд. техн. наук : 21.06.01 / Львів, 2015. 199 с.

13. Потомов М. А. Перспективы применения кавитационных технологий для интенсификации химико-технологических процессов. Вестник ТГТУ. 2008. Т.14, № 4. С.861-869.

14. Разумовский С. Д., Заиков Г. Е. Озон и его реакции с органическими соединениями (кинетика и механизм). М.: Наука, 1974. $322 \mathrm{c}$.

\section{References}

1. Yakovlev, S.V. (1986). Industrial wastewater treatment [Ochistka proizvodstvennykh stochnykh vod], M.: Stroiizdat. $336 \mathrm{p}$.

2. Kucherov, A.V., Shibileva, O.V. (2014). Water desalination: current state and development prospects [Opresneniie vody: sovremennoie sostoianiie i perspektivy razvitiia], Young Scientist. No. 3 (62), p. $236-239$.

3. Zapolski, A.K., Myshkova-Klymenko, N.A., Astrelin, I.M. etc. (2000). Physico-chemical bases of sewage treatment technology [Fizyko-khimichni osnovy tekhnologii ochyshchennia stichnykh vod], Kiev: Vyd-vo Libra. 552 p.

4. International Atomic Energy Agency. (2005). Predisposal Management of Low and Intermediate Level Radioactive Waste, IAEA Safety Series, No. WS-G-2.5, IAEA, Vienna.

5. Kostin, N.A., Kublanovsky, V.S., Zabludovsky, V.A. (1989). Impulsed electrolysis [Impulsnyi elektroliz], Academy of Sciences of the USSR. Institute of General and Inorganic Chemistry. Kiev: Naukova Dumka. 167 p.

6. Demidyuk, V.I., Tkachenko, S. N., Egorova, G.V., Popkovich, M.P., Lunin, V.V. (1998). Ozone decomposition on hard surfaces [Razlozheniie ozona na tverdykh poverkhnostiakh]. Third International Congress «Water: Ecology and technology». Proceedings. Moscow. p. 649-650. 
7. Kylskii, L.A., Knyazkova, T. V., Klymenko, N. A. (1988). Prospects for membrane purification of industrial water from surfactants and dyes [Perspektivy membrannoi ochistki promyshlennykh vod ot poverkhnostno-aktivnykh veshchestv i krasitelei], Moscow: D.Mendeleev University of Chemical Technology of Russia. 46 p.

8. Klymenko, N. A., Koganovsky, A. M., Panchenko, N. P. (1982). The use of activated carbons for the purification of industrial wastewater from surfactants [Ispolzovaniie aktivnykh uglei dlia ochistki promyshlennykh stochnykh vod ot PAVl, Water Chemistry and Technology. V. 4. No. 1, p. 47-50.

9. Kylskii, L. A., Strokach, P. P., Slipchenko, V. A. (1978). Electrocoagulation water purification [Ochistka vody elektrokoaguliatsiiei], Kiev: Budivelnyk. 112 p.

10. Arustamov, A. E., Zinin, A. V., Krasnikov, P. V. etc. (2005). The method of ion-selective cleaning of liquid radioactive waste from nuclear power plants [Metod ionoselektivnoi ochistki zhydkikh radioaktivnykh otkhodov atomnykh stantsii], Life Safety. No. 11, available at: d $=296$

ttp://www.proatom.ru/modules.php?name $=$ News \&file $=$ article \&s

11. Pivovarov, A. A., Nikolenko, N. V., Zaharov, R. I. etc. (2012) Thermodynamic analysis of chemical transformations in plasma-activated aqueous solutions of sodium chloride [Termodinamicheskii analiz khimicheskikh prevrashchenii $\mathrm{v}$ aktivirovannykh plazmoi vodnykh rastvorakh khlorida natriia], Questions of Chemistry and Chemical Technology. No. 3. p.127-133.

12. Predsimirska, L. M. (2015). Cavitation purification of natural and sewage waters from organic and biological contaminants [Kavitatsiine ochyshchennia pryrodnykh i stichnykh vod vid organichnykh ta biologichnykh zabrudnen]. (Thesis for PhD in Technical Sciences: 21.06.01). Lviv. 199 p.

13. Potomov, M. A. (2008). Prospects for the use of cavitation technology for the intensification of chemical-technological processes [Perspektivy primeneniia kavitatsionnykh tekhnologii dlia intensifikatsii khimiko-tekhnologicheskikh protsessov], TSTU Newsletter, V. 14. No. 4, p. $861-869$.

14. Razumovski, S. D., Zaikov, G. E. (1974). Ozone and its reactions with organic compounds (kinetics and mechanism) [Ozon i yego reaktsii s organicheskimi soedineniiami (kinetika i mekhanizm)], Moscow: Nauka. 322 p.

\section{Очистка жидких радиоактивных отходов от поверх- ностно-активных веществ и органических соединений}

Хуссам Ганем ${ }^{2}$, Герлига В. А.' ${ }^{1}$ Кравченко В. П. ${ }^{2}$, Македон В. В.' ${ }^{1}$, Шульга А. В. ${ }^{1}$

${ }^{1}$ Обособленное подразделение «Научно-технический центр» ГП НАЭК “Энергоатом», г Одесса, Украина

2 Одесский национальный политехнический университет, г. Одесса, Украина

В процессе эксплуатации АЭС образуется и накапливается значительное количество жидких радиоактивных отходов (ЖРО), пере работка которых является одной из первоочередных задач. Одним из источников жидких радиоактивных отходов являются трапные воды, в состав которых входят поверхностно-активные вещества (ПАВ) и органические соединения (OC) различной природы. При данном составе отходов значительно усложняется работа испарительных аппаратов. Поэтому, переработка вод существенно упрощается после их очистки от ПАВ и ОС. В работе рассмотрены теоретические аспекты окислительно-кавитационной и электро-гидророзрядной очистки вод от органических веществ. Разработаны и приведены принципиальные схемы экспериментальных стендов комбинированных методов очистки. Исследования проводили на модельных растворах лаурилсульфата натрия (ЛС) ( $\left.\mathrm{NaC}_{12} \mathrm{H}_{25} \mathrm{SO}_{4}\right)$ и этилендиаминтетрауксусной кислоты (ЭДТА) $\left(\mathrm{C}_{10} \mathrm{H}_{16} \mathrm{~N}_{2} \mathrm{O}_{8}\right)$. ЛС выбран ввиду того, что это наиболее распространенное ПАВ, которое присутствует в составе различных моющих и дезактивирующих смесей. Использование ЭДТА обусловлено его применением в технологических процессах на АЭС и наличием в составе жидких радиоактивных отходов. Разрушение ОС происходит в результате окисления озоном, который постоянно барботирует через раствор, и усиливается действием электрических импульсов или ультразвуковой (УЗ) кавитацией. В работе определены закономерности снижения концентраций модельных растворов в зависимо сти от способа обработки, рН-среды и продолжительности процесса. Установлено, что деструкция ПАВ и ОС лучше протекает при совместном использовании озона и УЗ кавитации или электрического разряда при высоких значениях рН. Самые высокие показатели эффективности очистки растворов следующие: использование разрядов и озона $(p H=6,2)$ разрушает около $71 \%$ ПАВ, при $\mathrm{pH}=10$ разрушается $~ 61 \%$ OC; использование УЗ кавитации и озона $(\mathrm{pH}=10)$ разрушает 83,3 \% $\Pi A B$.

Ключевые слов а: очистка воды от поверхностно-активных веществ и органических соединений, электро-гидророзрядний метод, окисление озоном

\section{Purification of Liquid Radioactive Waste from Surfactants and Organic Compounds}

\section{Hussam Ghanem ${ }^{2}$, Gerlyga V. ${ }^{1}$, Kravchenko V. ${ }^{2}$, Македон V. ${ }^{1}$} Shulga A. 1

1 SS STC DSTSO SE «NNEGC «Energoatom», Odessa, Ukraine

${ }^{2}$ Odessa National Polytechnic University, Odessa, Ukraine

During the operation of a nuclear power plant, a significant amount of liquid radioactive waste ( $L R W)$ is formed and accumulated, its recycling has one of the first priorities. One of the sources of liquid radioactive waste is drain water, which consists of surface-active substances (SA) and organic compounds (OC) of various natures. With this waste composition, the operation of the evaporator is significantly complicated. Thus, recycling of LRW will be simplified after purification from SA and OC. The paper discusses the theoretical aspects of oxidative-cavitation and electrohydrodischarge water purification from organic matter. A schematic circuit of experimental stands of combined cleaning methods was developed and presented. Studies were performed on model solutions of sodium lauryl sulfate (LS) ( $\left.\mathrm{NaC}_{12} \mathrm{H}_{25} \mathrm{SO}_{4}\right)$ and ethylenediaminetetraacetic acid (EDTA) $\left(\mathrm{C}_{10} \mathrm{H}_{16} \mathrm{~N}_{2} \mathrm{O}_{8}\right)$. LS is chosen because it is the most common SA, which is present in the composition of various detergent and decontamination mixtures. The use of EDTA is due to its application in technological processes at nuclear power plants and the presence of liquid radioactive waste in the composition. The destruction of the OS occurs as a result of ozone oxidation, which is constantly splashing through the solution, and amplifies under the action of electrical impulses or ultrasonic(US) cavitation. The work identifies the patterns of reducing concentrations of model solutions, depending on the method of processing, $\mathrm{pH}$-environment and duration of the process. It was found that the destruction of SA and OC occurred better when ozone was combined with US cavitation or electrical discharge, at high $\mathrm{pH}$. The highest performance purification of solutions is as follows: use of electro-discharge and ozone $(p H=6.2)$ leads to about $71 \%$ collapses, $(p H=10) \sim 61 \%$ OC collapses; use of US cavitation and ozone $(p H=10) \sim 83.3 \%$ SA collapses.

Keywords: water purification from surfactants and organic compounds, electro-hydraulic discharge method, ozone oxidation 